\title{
Hydrogen-The Bridge Between Africa and Europe
}

\author{
Ad van Wijk and Frank Wouters
}

\begin{abstract}
This chapter describes a European energy system based on 50\% renewable electricity and $50 \%$ green hydrogen, which can be achieved by 2050 . The green hydrogen shall consist of hydrogen produced in Europe, complemented by hydrogen imports, especially from North Africa. Hydrogen import from North Africa will be beneficial for both Europe and North Africa. A bold energy sector strategy with an important infrastructure component is suggested, which differs from more traditional bottom-up sectoral strategies. This approach guarantees optimized use of (existing) infrastructure, has low risk and cost, improves Europe's energy security and supports European technology leadership. In North Africa it would foster economic development, boost export, create future-oriented jobs in a high-tech sector and support social stability.
\end{abstract}

\section{Introduction}

Electrification is one of the megatrends in the ongoing energy transition. Since 2011, the annual addition of renewable electricity capacity has outpaced the addition of coal, gas, oil and nuclear power plants combined, and this trend is continuing. Due to the recent exponential growth curve and associated cost reduction, solar and wind power in good locations are now often the least cost option, with production cost of bulk solar electricity in the sunbelt soon approaching the $1 \$ \mathrm{ct} / \mathrm{kWh}$ mark. However, electricity has limitations in industrial processes requiring high temperature heat, chemicals feedstock or in bulk and long-range transport.

Green hydrogen made from renewable electricity and water will play a crucial role in our decarbonized future economy, as shown in many recent scenarios. In a system soon dominated by variable renewables such as solar and wind, hydrogen links electricity with industrial heat, materials such as steel and fertilizer, space heating, and

\footnotetext{
A. van Wijk ( $\square)$

Delft University of Technology, Delft, The Netherlands

e-mail: a.j.m.vanwijk@tudelft.nl

F. Wouters

Worley, Masdar City, Abu Dhabi, UAE

(C) The Author(s) 2021

M. P. C. Weijnen et al. (eds.), Shaping an Inclusive Energy Transition,

https://doi.org/10.1007/978-3-030-74586-8_5
} 
transport fuels. Furthermore, hydrogen can be seasonally stored and transported cost-effectively over long distances, to a large extent using existing natural gas infrastructure. Green hydrogen in combination with green electricity has the potential to entirely replace hydrocarbons.

Due to its limited size and population density, Europe will not be able to produce all its renewable energy in Europe itself. Therefore, it is assumed that a large part of the hydrogen will be imported. Although hydrogen import can come from many areas in the world with good solar and wind resources, an interesting possibility is the import from North Africa. Already today, $13 \%$ of the natural gas and $10 \%$ of the oil consumed in Europe come from North Africa (Eurostatimports, 2019) and 60\% of North Africa's oil exports and $80 \%$ of its gas exports are sent to Europe.

North Africa has good solar and wind resources and many countries are developing ambitious renewable energy strategies to cater for growing energy demand of urban and industrial centers, but also electrify the unserved parts of the population in remoter areas. Low-cost and price-stable renewable electricity has the potential to spur economic growth, necessary to stabilize societies and reduce economic migration. However, over and beyond catering for domestic demand, most North African countries have huge potential in terms of land and resources to produce green hydrogen from solar and wind for export. The resources in North Africa are vast. Only $8 \%$ of the Sahara Desert covered with solar panels suffice to produce all the energy for the world, 155,000 TWh per year (Wijk et al., 2017).

If Europe and North Africa can develop a joint hydrogen economy, both North Africa and Europe will benefit. Only the Mediterranean Sea separates the two regions. Hydrogen can be imported from North Africa by pipeline, which is more cost effective than import by ship. With hydrogen imported from North Africa, Europe could realize a sustainable energy system, required to meet the obligations of the Paris Agreement, faster and cheaper. Furthermore, a joint European-North African renewable energy and hydrogen approach would create economic development, future-oriented jobs and social stability in North-African countries, potentially reducing the number of economic migrants from the region to Europe.

\section{Renewable Energy Resources in Europe and North Africa}

In Europe, good renewable energy resources are geographically distributed. However, they are not evenly distributed among the EU member states and therefore large scale, pan-European energy transport and storage is necessary.

Large scale on- and offshore wind can be produced at competitive and subsidy free prices in several parts of Europe. Large scale offshore wind has great potential in the North Sea, Irish Sea, Baltic Sea and parts of the Mediterranean Sea. And largescale onshore wind potential can be found especially in Greece, the UK, Ireland and in many other coastal areas in Europe such as Portugal, Poland and Germany. Large scale solar PV can also be built competitively and subsidy-free, most notably in Southern Europe, for instance in Spain, Italy and Greece. 
Furthermore, low cost hydropower electricity can be produced in Iceland, Norway, Sweden, Austria, Switzerland, etc. and geothermal electricity in Iceland, Italy, Poland and Hungary. Although, the potential expansion of the hydropower and geothermal capacity is limited, the future introduction of marine/tidal energy converters could furthermore augment the production of renewable electricity and hydrogen in the UK, Portugal, Norway and Iceland.

In North Africa, however, the solar energy resources are even better than in Southern Europe. The Sahara Desert is the world's sunniest area year-round. It is a large area (more than 9.2 million square kilometer) that receives, on average, $3600 \mathrm{~h}$ of sunshine yearly and in some areas $4000 \mathrm{~h}$. This translates into solar insolation levels of 2500-3000 kWh per square meter per year (Varadi et al., 2018). A fraction of the Sahara Desert's area could generate the globe's entire electrical demand.

Also, it should be noted that the Sahara Desert is one of the windiest areas on the planet, especially on the west coast. Average annual wind speeds at ground level exceed $5 \mathrm{~m} / \mathrm{s}$ in most of the desert and reach $8-9 \mathrm{~m} / \mathrm{s}$ in the western coastal regions. Wind speeds also increase with height above the ground, and the Sahara winds are quite steady throughout the year (Varadi et al., 2018). Also, Egypt's Zaafarana region is comparable to Morocco's Atlantic coast, with high and steady wind speeds, critical for the economics of wind energy as the energy derived from a wind turbine scales at the third power of the speed of the air passing through its blades. In Morocco, Algeria and Egypt certain land areas have wind speeds that are comparable to offshore conditions in the Mediterranean, Baltic Sea and some parts of the North Sea.

One should consider the difference between countries that are net energy importers, such as Tunisia and Morocco, and net exporters such as Algeria, Libya and Egypt. Morocco has been leading the pack and is embarking on an ambitious renewable journey, building world class solar and wind projects to increase energy security, reduce cost, emissions and price volatility and support economic growth. For Algeria and Egypt, tapping into low-cost renewables reduces overall system cost and frees up fossil fuels for higher value applications and export.

Large scale solar PV, Concentrating Solar Power and wind can be realized in North African countries against production cost lower than in Europe. The expectation is that solar PV and wind onshore production cost in North Africa will come down to 1 \$ct/kWh before 2030 (Fig. 1).

\section{Energy in Europe}

Energy carriers are used for heating, mobility, electricity and in industry for high temperature heat and as a feedstock. In 2017, the total energy consumption (Gross Available Energy) in the European Union amounted to 1719 Mtoe or almost 20,000 TWh (EurostatEnergy, 2019). Final energy consumption in 2017, the energy consumed by end users, was 1123 Mtoe or about 13,000 TWh, see Table 2. The European Union is a net energy importer, with 55\% of the 2017 energy needs (Gross Available Energy) met by imports, consisting of oil and oil products, natural gas and 


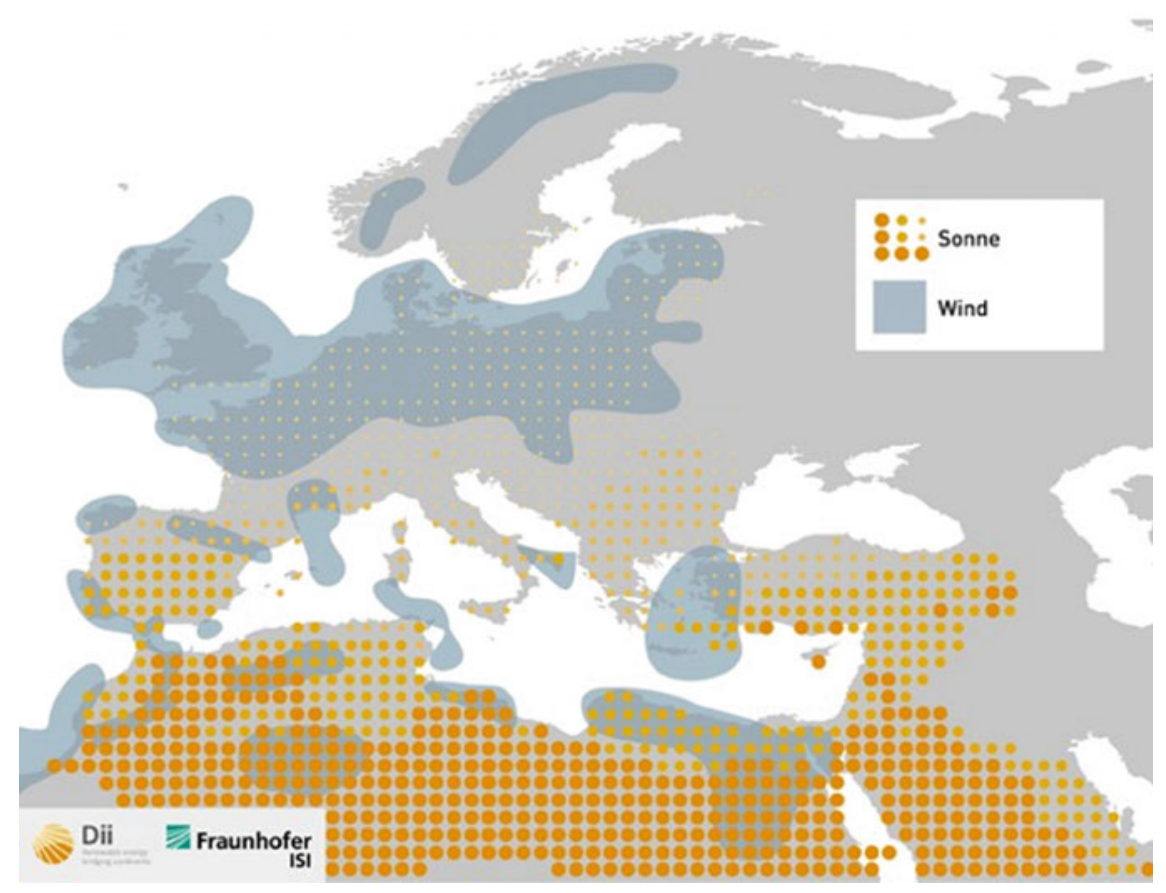

Fig. 1 Solar irradiation and wind speed in Europe and North Africa. North Africa has world class solar and wind resources (Dii \& Fraunhofer ISI, 2012)

solid fuels. Although Europe is working ambitiously to become less dependent on energy imports, it is unlikely that it can become entirely energy self-sufficient. Most scenarios, including BP's Energy Outlook 2019 (BP, 2019) indicate that Europe shall remain a net importer of energy until mid-century and beyond. Given the population density and comparatively limited potential for renewable energy, the expectation is that Europe shall continue to import energy, also in a future renewable energy system. However, instead of fossil fuels, over time Europe shall import energy in the form of green electrons, but especially in the form of green molecules (Table 1).

To meet their obligations under the Paris Agreement, the EU Member States have set key targets for 2030: (1) a 40\% cut in greenhouse gas emissions compared to 1990 levels, (2) at least a 32\% share of renewable energy consumption and (3) an improvement in energy efficiency at EU level of at least 32.5\%. The corresponding EU 2030 goal for final energy consumption is set at 11,118 TWh (Eurostat, 2019).

Beyond that, the European Commission calls for a climate-neutral Europe by 2050, laid down in the document "A Clean Planet for all", which was released in November 2018 (European Commission, 2018). The fuel mix in Gross Inland Consumption, that is projected in 2050, under different scenarios, is shown in Fig. 2. In all these 2050 scenarios fossil fuels and nuclear still have a significant share. There is a current debate ongoing about which scenario is most appropriate for 
Table 1 EU28 2017 energy consumption

(EurostatEnergy, 2019)

\begin{tabular}{l|r|l}
\hline 2017 EU28 & \multicolumn{1}{|l}{ Mtoe } & \multicolumn{1}{l}{ TWh } \\
\hline Gross available energy & 1,719 & 19,993 \\
\hline - International maritime bunkers & -45 & -523 \\
\hline Gross inland consumption & $1,663^{\mathrm{a}}$ & 19,341 \\
\hline - Feedstock & -102 & $-1,191$ \\
\hline Primary energy consumption & 1,561 & 18,150 \\
\hline - Conversion losses energy sector & -438 & $-5,094$ \\
\hline Final energy consumption & 1,123 & 13,056 \\
\hline
\end{tabular}

${ }^{\mathrm{a}}$ Ambient heat (11 Mtoe) is also subtracted (EurostatGuide, 2019)

Table 2 EU28 2017 Final energy consumption (Eurostat Energy, 2019)

\begin{tabular}{l|r|r}
\hline 2017 EU28 & TWh & $\%$ \\
\hline Oil & 4,584 & 35 \\
\hline Gas & 2,783 & 21 \\
\hline Electricity & 2,798 & 21 \\
\hline Renewables + Biofuels & 1,190 & 9 \\
\hline Solid fuels & 298 & 2 \\
\hline Other & 1,404 & 11 \\
\hline Final energy consumption & 13,056 & 100
\end{tabular}

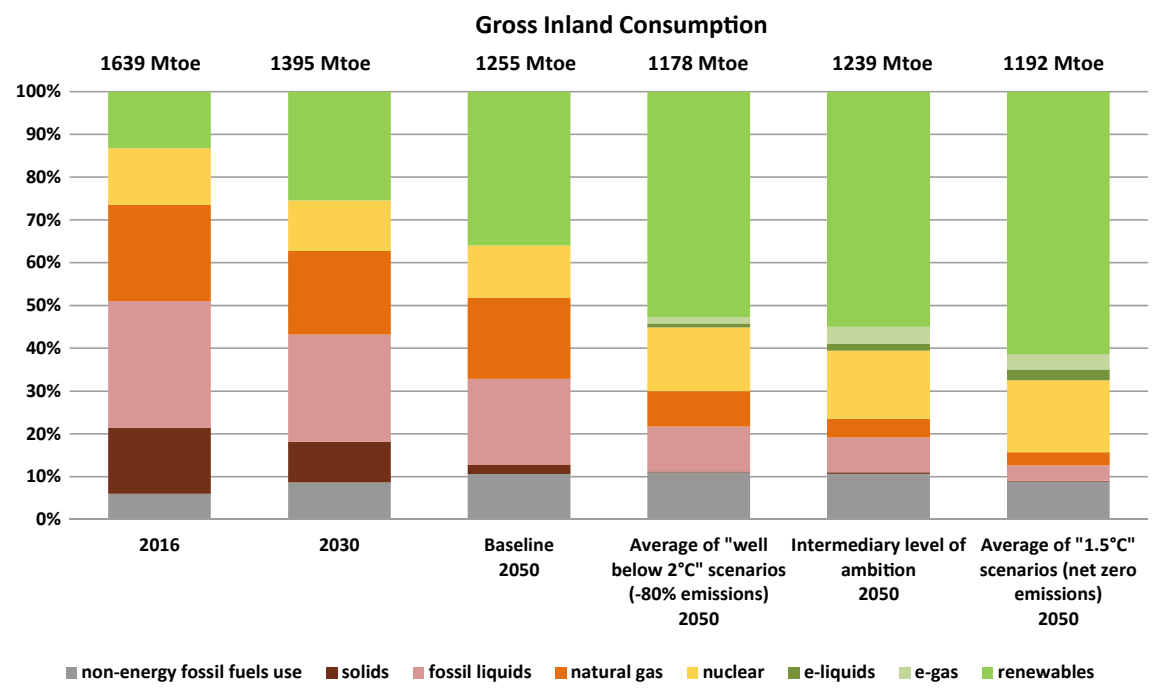

Fig. 2 Fuel mix for gross inland consumption EU28, projected for 2050, for different scenarios from the EU document 'A clean planet for all' (European Commission, 2018) 
Table 3 Solar and wind energy in the European union in 2050, according to several scenarios

\begin{tabular}{l|l|l|l|l}
\hline Scenario & $\begin{array}{l}\text { Solar energy } \\
{[\mathrm{TWh} / \mathrm{a}]}\end{array}$ & $\begin{array}{l}\text { Wind energy } \\
{[\mathrm{TWh} / \mathrm{a}]}\end{array}$ & $\begin{array}{l}\text { Solar capacity } \\
{[\mathrm{GW}]}\end{array}$ & $\begin{array}{l}\text { Wind capacity } \\
{[\mathrm{GW}]}\end{array}$ \\
\hline Shell sky scenario & 3,472 & 3,089 & 2,300 & 1,000 \\
\hline $\begin{array}{l}\text { DNV GL energy } \\
\text { transition outlook } \\
2018\end{array}$ & 1,077 & 1,662 & 718 & 554 \\
\hline LUT/EWG & & & 2,000 & 560 \\
\hline
\end{tabular}

Europe, with several European member states arguing that Europe needs to pursue a 100\% renewable energy scenario (Morgan, 2019).

Several recent scenarios exist for Europe's energy system in 2050, including Shell's Sky Scenario (Shell, 2018), The Hydrogen Roadmap for Europe (FCHJU 2019), DNV-GL's Energy Transition Outlook 2018 (DNV-GL 2018) and the "Global Energy System based on 100\% Renewable Energy-Power Sector" by the Lappeenranta University of Technology (LUT) and the Energy Watch Group (EWG) (Ram et al., 2017). The following table contains a summary of the most ambitious renewable energy shares in each of these modeling exercises (Table 3).

It should be noted that to achieve the binding Paris Agreement, Europe's electricity sector needs to be fully decarbonized by 2050 and other energy sectors to a large extent also. This is a prerequisite for the Shell, GWEC and LUT/EWG scenarios. However, the DNV-GL ETO scenario is not compatible with keeping global warming well below $2{ }^{\circ} \mathrm{C}$. It is reasonable to assume that for the DNV-GL scenario to be compatible with the Paris Agreement, the amount of solar energy would be closer to the results of the other scenarios. Analyzing and comparing these scenarios, one can assume that some $2,000 \mathrm{GW}$ of solar and $650 \mathrm{GW}$ of wind energy capacity can be installed by 2050, generating roughly 2,800 TWh of solar energy and 2,000 TWh of wind energy per year.

Most scenarios consider a drawn-out transition process, with a continuing dependency on fossil fuels, most of them imported, that will last for decades and would lead to climate chaos if released in the atmosphere. Since the associated emissions are incompatible with the Paris Agreement, several scenarios therefore feature massive investments in carbon capture and storage as well as future carbon sinks, mostly achieved through forestation. The Shell Sky scenario for example, contains a staggering 10,000 CCS projects necessary to limit $\mathrm{CO}_{2}$ emissions. As of 2019, there are 21 CCS projects in the world (Carbon Capture and Storage, 2019) and less than 7000 coal fired power plants, so it would require a huge effort, technically, financially as well as regarding popular sentiment, to realize this many CCS projects. The question is whether there are no better alternatives altogether. 


\section{Energy in North Africa}

The Southern Mediterranean countries can be currently divided into net energy importing and net energy exporting countries. Libya and Algeria have built their economies on the back of their substantial oil and gas reserves, whilst Morocco has always had to import fossil fuels. Egypt's recent offshore gas finds are expected to make the country a net natural gas exporter, joining Algeria and Libya. In the African context, in North Africa less than $2 \%$ of the population is without access to electricity. In contrast, $50 \%$ of people in West Africa and $75 \%$ in East Africa lack access to electricity. North Africa on average consumes eight times more electricity per capita than the rest of the continent, excluding South Africa (IRENA, 2015).

IRENA's Renewable Energy roadmap for Africa 2030 (IRENA, 2015) has analyzed options for the doubling of renewable energy supply by 2030 in a bottomup approach. Supported by the excellent solar and wind resources in North Africa, it showed a feasible expansion to almost $120 \mathrm{GW}$ by 2030, of which $70 \mathrm{GW}$ would be wind and the remainder a combination of CSP (Concentrating Solar Power) and PV.

Morocco is an interesting example, as they have embarked on an ambitious renewable energy program with a target of $42 \%$ of renewable electricity by 2020 . The state-owned entity MASEN plays a pivotal role. MASEN pre-develops renewable energy sites, carries through the procurement process, acts as the government entity borrowing concessional finance from development finance institutions and commercial lenders, and co-invests on behalf of the government. In Ouarzazate, a city in the south of Morocco's High Atlas Mountains they have built the Noor solar complex, consisting of CSP and PV projects, totaling $582 \mathrm{MW}$ at peak when finished. The scale of these projects and Morocco's clever financial engineering have brought down the cost of CSP, which is now competitive with conventional power.

\section{Hydrogen in Europe and North-Africa}

Green hydrogen can be produced in electrolyzers using renewable electricity, can be transported using the natural gas grid and can be stored in salt caverns and depleted gas fields to cater for seasonal mismatches in supply and demand of energy (HyUnder, 2013). Like with natural gas, underground storage would be seasonal, while linepacking flexibility provides some short-term storage.

It should be noted that blue hydrogen, hydrogen produced from fossil fuels and combined with CCS, can play an important role in an intermediate period, helping kickstart hydrogen as an energy carrier alongside the introduction of green hydrogen. 


\section{Production Cost of Hydrogen}

Renewable electricity is rapidly becoming cheaper than conventional electricity made in nuclear, gas- or coal-fired power plants. Already to date, solar power in Southern Europe and offshore wind in the North Sea does not require subsidy but can be sold at market prices. In North Africa, however, the electricity production costs with solar and wind are even lower than in Europe.

Green hydrogen is currently not cost-competitive compared to hydrogen made from hydrocarbons. Although for every ton of hydrogen produced today using steam methane reforming some 10 tons of $\mathrm{CO}_{2}$ are released in the atmosphere, the price of carbon is not reflective of the cost to the global economy. There is no market yet for green hydrogen and electrolyzer manufacturers lack scale, resulting in relatively high cost of equipment. However, if a market would develop, hydrogen can be produced on locations with good solar or wind resources at $€ 1$ per $\mathrm{kg}$.

In January 2019, Morocco announced bids of $€ 28$ per MWh for an $850 \mathrm{MW}$ wind farm. The expectation is that electricity production cost will further drop to $€$ 10-20 per MWh before 2030 at sites with good solar and wind resources throughout North Africa. Combinations of solar and wind, or even wind alone, will have load factors of 4,000-5,000 hours per year. With electrolyzer efficiencies of $80 \%$ (HHV, higher heating value) and CAPEX of $€ 300$ per $\mathrm{kW}$, the levelized cost of hydrogen production will be about $€ 1$ per $\mathrm{kg}$, see Fig. 3 .

In Europe, however, with higher electricity production cost for solar and wind than in North Africa, the hydrogen production cost is expected to be $€ 0.5-1.0$ per $\mathrm{kg}$ higher than in North Africa by 2030. But in 2050, with lower electricity production cost, higher electrolyzer efficiencies and lower CAPEX the hydrogen production cost

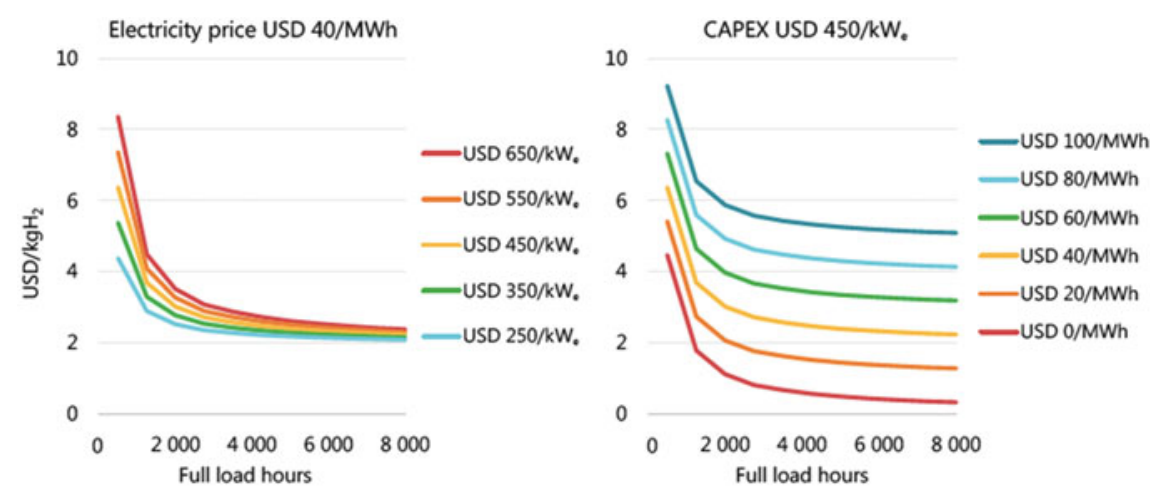

Notes: MWh = megawatt hour. Based on an electrolyser efficiency of $69 \%$ (LHV) and a discount rate of $8 \%$.

Source: IEA 2019. All rights reserved.

Fig. 3 Future levelized cost of hydrogen production by operating hour for different electrolyzer investment costs (left) and electricity costs (right), from the future of hydrogen (IEA, 2019). (LHV Lower Heating value of hydrogen is $120 \mathrm{MJ} / \mathrm{kg}$. HHV Higher Heating Value of hydrogen is $141.7 \mathrm{MJ} / \mathrm{kg}$. An efficiency of $69 \%$ on LHV is equal to an efficiency of $81 \%$ on $\mathrm{HHV}$ ) 
will come down to $€ 1$ per $\mathrm{kg}$ in Europe too. However, the production cost in North Africa, in 2050 will also drop and be well below $€ 1$ per $\mathrm{kg}$.

\section{Infrastructure in Europe}

In Europe, the lowest cost renewable resources are hydropower in Norway and the Alps, offshore wind in the North Sea and the Baltic Sea, onshore wind in selected European areas, whereby the best solar resource is in Southern Europe. The current electricity grid was not built for this, is not fit for the energy transition and needs to be drastically modernized. In 2018, an estimated $€ 1$ billion worth of offshore wind energy was curtailed in Germany due to insufficient transmission grid capacity, according to the German Federal Network Agency (Bundesnetzagentur, 2019). In addition, the development of new renewable energy capacity is slowed down due to the lack of grid capacity. Unfortunately, overhead power lines are difficult to realize due to environmental concerns, popular opposition and typically take more than a decade for planning, permitting and construction.

However, a gas grid is much more cost-effective than an electricity grid: for the same investment a gas pipe can transport 10-20 times more energy than an electricity cable. Also, Europe has a well-developed gas grid that can be converted to accommodate hydrogen at minimal cost. Recent studies carried out by DNV-GL (2017) and KIWA (2018) in the Netherlands concluded that the existing gas transmission and distribution infrastructure is suitable for hydrogen with minimal or no modifications. So instead of transporting bulk electricity throughout Europe, a more cost-efficient way would be to transport green hydrogen and have a dual electricity and hydrogen distribution system. Figure 4 shows the existing European natural gas grid (blue) and a hydrogen backbone (orange) as suggested by the $2 \times 40 \mathrm{GW}$ Green Hydrogen Initiative, Hydrogen Europe (Wijk \& Chatzimarkakis, 2020). Such a hydrogen backbone would link the areas of low-cost renewable electricity with the load centers in Europe. Operational by 2030-2035, it could be the first phase to realize a full conversion from natural gas to hydrogen by 2050 .

The cost to build new hydrogen pipelines is comparable with the cost to build new natural gas pipelines. Europe also has an extensive network of offshore gas pipelines, an example of which is the Nordstream pipeline between Russia and Germany, 1,224 km long, with an investment cost of 7.4 billion Euro and a design capacity of $55 \mathrm{bcm} / \mathrm{annum}$, or $68 \mathrm{GW}$ (Nordstream, 2017). The Nordstream pipeline consist of 2 pipes with a diameter of 48 inch each. This pipeline was commissioned in October 2012 and has been upgraded over the years. In 2018, $58.8 \mathrm{bcm}$ or $630 \mathrm{TWh}$ natural gas was transported by Nordstream to Europe. An analysis of the investment cost for several of these large-scale pipelines shows an average turnkey investment cost of 1 million Euro per $10 \mathrm{GW}$ per $\mathrm{km}$. 


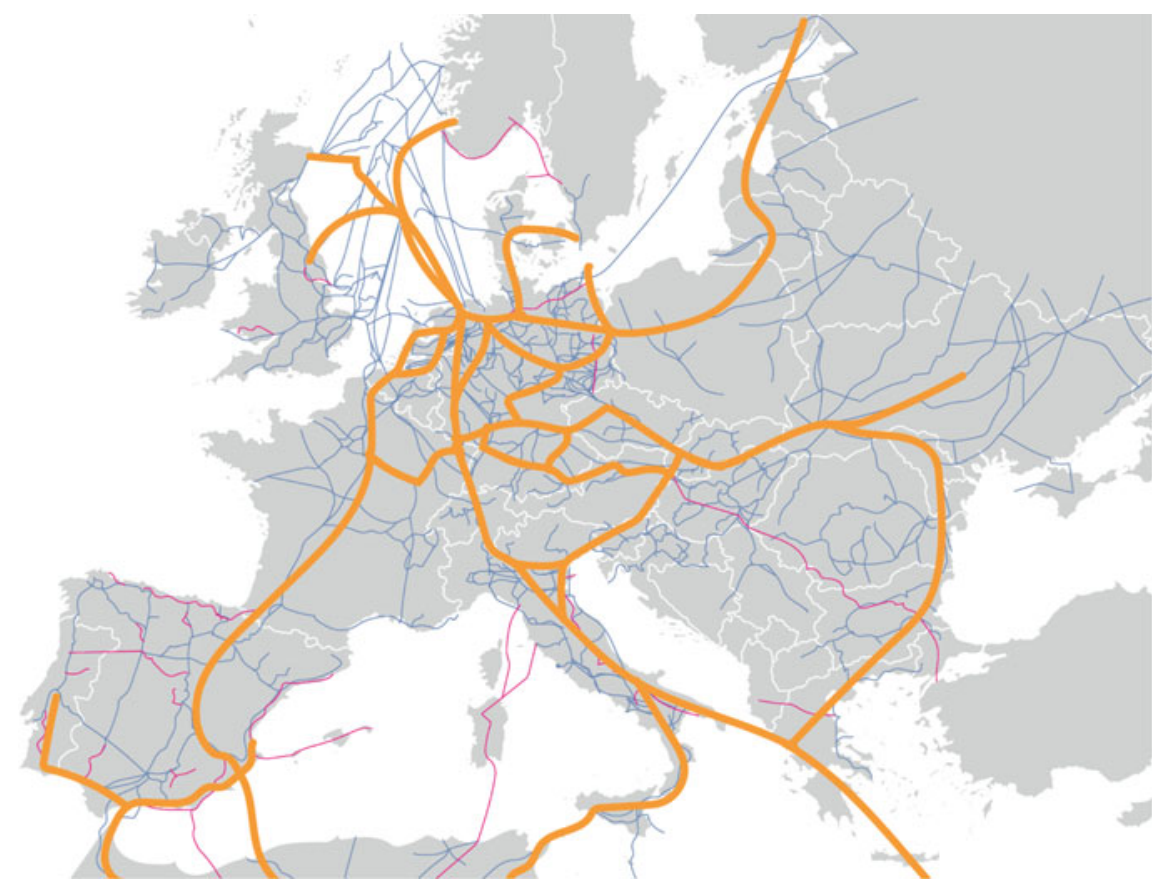

Fig. 4 Natural gas infrastructure in Europe (blue and red lines) and first outline for a hydrogen backbone infrastructure (orange lines). The main part of the hydrogen backbone infrastructure consists of re-used natural gas transport pipelines with new compressors. A new pipeline from the solar and wind resource areas in Greece needs to be realized

\section{Infrastructure Europe-North Africa}

The electricity grid infrastructure in North Africa is not well developed, requiring major reinforcements and expansion in the coming decades, especially to transport electricity from the good solar and wind resource areas to the demand centers in the cities and rural areas.

Today, there are only two electricity grid connections between Europe and North Africa, each 700 MW grid interconnectors between Spain and Morocco. In the beginning of the century, the Desertec vision proposed to produce large amounts of solar and wind electricity in North Africa and expand the interconnection between Africa and Europe, enabling the export of part of this electricity to Europe across the Mediterranean. The cost to build such an electricity grid was huge, so even with lower production cost in North Africa, it was difficult for the imported electricity to compete with solar and wind electricity produced in Europe.

However, there is a gas transport infrastructure available between North Africa and Europe, transporting gas from Algeria and Libya to Europe via Italy and Spain. The gas transport volume through these pipelines is over $63.5 \mathrm{bcm}$ per year, which equals a capacity of more than $60 \mathrm{GW}$ (Timmerberg \& Kaltschmitt, 2019). 

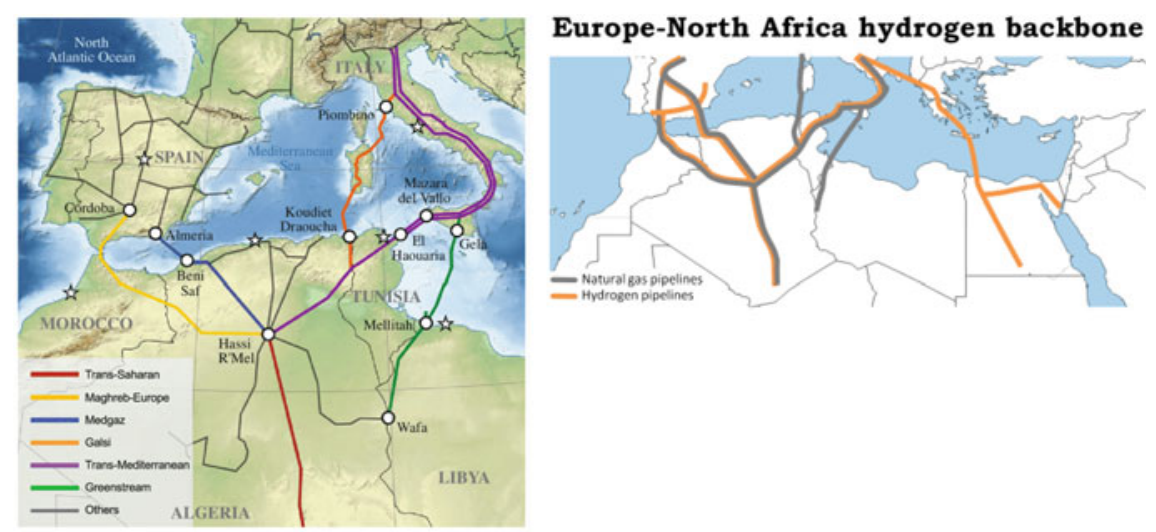

Fig. 5 Natural gas infrastructure Europe-North Africa (left figure) and first outline for a hydrogen backbone infrastructure Europe-North Africa (figure above) An existing gas infrastructure from Algeria and Morocco could be converted to a hydrogen infrastructure (grey-orange lines). A "new" hydrogen transport pipeline must be realized from Italy to Greece, crossing the Mediterranean Sea to Egypt, which could eventually be extended to the Middle East (orange line)

In a first phase, between 2030 and 2035, the natural gas infrastructure could be used to transport hydrogen from North Africa to Europe. In an initial phase, a substantial hydrogen volume can be produced by converting natural gas to hydrogen, whereby the $\mathrm{CO}_{2}$ is stored in empty gas/oil fields (blue hydrogen). Over the years however, with ever declining cost of renewable electricity and electrolyzers, more and more green hydrogen from solar and wind electricity can be fed into these pipelines.

Next to converting existing pipeline infrastructure, new hydrogen gas pipeline infrastructure could be built, connecting the good solar and wind resources in North Africa to Europe. A first new pipeline could be realized to connect Egypt and Greece to the main European gas grid in Italy, see Fig. 5.

The realization of a hydrogen "South-Nordstream" from Egypt, via Greece to Italy, $2,500 \mathrm{~km}$, with a similar capacity as the actual Nordstream, with $66 \mathrm{GW}$ capacity, consisting of 2 pipelines of 48 inch each, would imply total investments of $€ 16.5$ billion. The cost figures are derived from the Nordstream project (Nordstream, 2014) and a study for US DOE (James et al., 2018). With a load factor of 4,500 h per year, an amount of $300 \mathrm{TWh}$ or 7.6-million-ton hydrogen per year can be transported. Given the assumptions, as shown in Table 4, the levelized cost for hydrogen transport by pipeline, is $0.005 € / \mathrm{kWh}$ or $0.2 € / \mathrm{kg} \mathrm{H} 2$, which is a reasonable fraction of the total cost of delivered hydrogen. 
Table 4 The energy transport volumes and levelized cost of hydrogen transport for a "SouthNordstream", connecting the good solar and wind resources in Egypt and Greece to the European gas grid in Italy

South-Nordstream: Egypt-Greece-Italy

Levelized cost of hydrogen transport by pipeline

Assumptions

\begin{tabular}{l|l|l}
\hline Pipeline diameter & inch & 48 \\
\hline Number of pipelines & & 2 \\
\hline Pipeline pressure & bar & 100 \\
\hline Pipeline flow speed & $\mathrm{m} / \mathrm{s}$ & 30 \\
\hline Pipeline capacity & $\mathrm{GW}$ & $2 * 33=66$ \\
\hline Pipeline length & $\mathrm{km}$ & 2,500 \\
\hline Specific investment cost & $€ / 10 \mathrm{GW} / \mathrm{km}$ & $1,000,000$ \\
\hline Capex (Total investment cost) & Billion $€$ & 16.5 \\
\hline O\&M cost (including compressor energy) & $\% \mathrm{Capex} / \mathrm{yr}$ & 1 \\
\hline WACC (Weighted average cost of capital) & $\%$ & 7 \\
\hline Lifetime & $\mathrm{yr}$ & 40 \\
\hline Load factor pipeline & $\mathrm{hr} / \mathrm{yr}$ & 4,500 \\
\hline Calculations & & \\
\hline Energy transport & $\mathrm{TWh} / \mathrm{yr}$ & 300 \\
\hline & Ton $\mathrm{H}_{2} / \mathrm{yr}$ & 7.6 million \\
\hline Levelized cost of hydrogen transport & $€ / \mathrm{kWh}$ & 0.005 \\
\hline & $€ / \mathrm{kg}$ & 0.2 \\
\hline
\end{tabular}

\section{Hydrogen Storage}

Energy supply and demand always need to be balanced. Balancing oil and coal supply and demand is relatively easy and cheap by storing oil in tanks and coal in bunkers or in the open air. However, balancing electricity and gas supply and demand is more challenging.

Electricity supply and demand needs to be balanced at any moment in time. Balancing the electricity system today is mainly done using pumped hydropower and by flexible power plants, especially gas fired power plants. Natural gas storage is therefore crucial today in balancing electricity supply and demand. But an even larger seasonal gas storage volume is needed to balance gas production and supply for space heating.

Natural gas demand in Europe, especially in Northern Europe, shows a strong seasonal variation, in wintertime, the gas demand is 2-3 times higher than in summertime. However, natural gas production is constant throughout the year. Therefore, large scale seasonal storage of natural gas is necessary. Natural gas is stored in empty gas fields, porous rock formations and salt caverns. The overall storage capacity in 
operation within the EU amount to $89.2 \mathrm{bcm}$ (871 TWh). The largest storage capacities for gas are in Germany, in total $21.8 \mathrm{bcm}(213 \mathrm{TWh})$. Half of this storage is in salt caverns, amounting to $10.9 \mathrm{bcm}$ (106.5 TWh) (Timmerberg \& Kaltschmitt, 2019). Germany has by far the largest gas storage capacity in salt caverns in Europe, but they are in use in several other countries too, see Fig. 7.

Total gas consumption in the EU in 2017 was 493 bcm (5,163 TWh) (Eurostatgas, 2019).

This total gas consumption includes 2,782 TWh as final gas consumption, with the remainder used as feedstock and for electricity production. The storage capacity is therefore $18 \%$ of total gas consumption in Europe. This storage capacity is especially necessary to balance large scale, seasonal, weekly and daily gas demand fluctuations especially for space heating and to a lesser extent for electricity. Part of this storage capacity is in use to store energy for strategic reserves.

In a future energy system, the share of electricity from variable sources such as solar and wind in the overall energy supply will dramatically increase. Although the share of electricity is expected to grow to $50 \%$ of all final energy demand, green molecules will be necessary for applications that are difficult or expensive to electrify. Due to the variability of renewable energy sources and the large fluctuations in energy demand for space heating and electricity, storage capacity is needed on an hourly, daily, weekly and seasonal scale. Capacitors and batteries will play a significant role for hourly and daily storage. For large scale, seasonal and weekly storage, hydrogen storage, replacing natural gas storage, will become crucial.

Several studies have examined the need for hydrogen in an electricity system that is increasingly based on renewable energy sources. Figure 6 shows how the need for hydrogen grows exponentially in a system with variable electricity sources, as
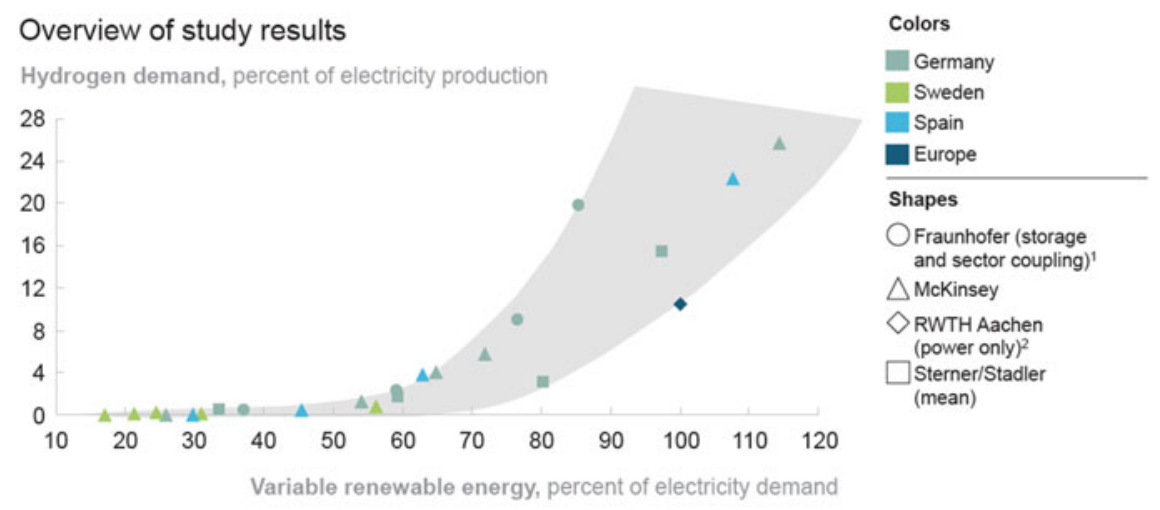

\footnotetext{
1 Least-cost modeling to achieve $2^{\circ} \mathrm{C}$ scenario in Germany in 2050 in hour-by-hour simulation of power generation and demand, assumptions: no regional distribution issues (would increase hydrogen pathway), no change in energy imports and exports

2 Simulation of storage requirements for $100 \%$ European RES; only power-sector storage considered (lower bound for hydrogen pattrway)

SOURCE: Fraunhofer Institute for Solar Energy Systerns ISE, 2017; BMW; RWTH Aachen; Stemer and Stadler (2014); McKinsey
}

Fig. 6 The need for hydrogen in the electricity system increases exponentially with increasing renewable energy share (Hydrogen council, 2017) 


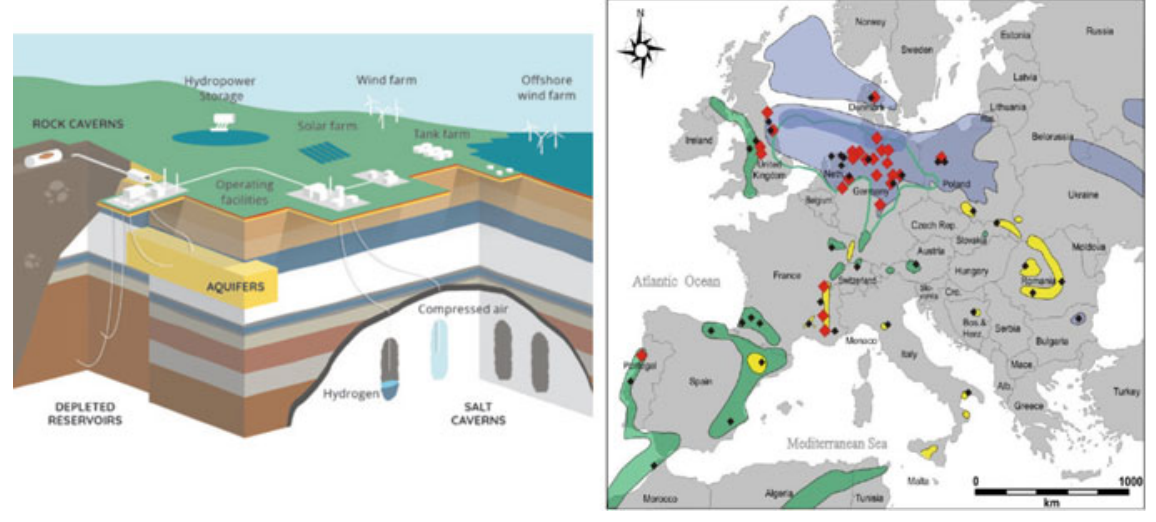

Fig. 7 Salt cavern (van Wijk, van der Roest and Boere 2017) (left) and salt formations with salt caverns throughout Europe (right). The red diamonds are salt caverns in use for natural gas storage (Bünger et al., 2016)

modeled by several institutions. When electricity systems are fully based on renewable energy sources, some $20 \%$ of variable electricity must be converted to hydrogen to guarantee a secure energy supply every time of the day and year.

The need for cheap hydrogen storage will grow exponentially over time. Salt caverns can provide this cheap hydrogen storage solution. Europe has still many empty salt caverns available for large scale hydrogen storage, but dedicated salt caverns for hydrogen storage capacity can be developed in the different salt formations in Europe. Potentially, hydrogen can be stored in empty gas fields that meet specific requirements to store hydrogen. However, this needs more research.

Salt caverns today are 'left over' from salt production. A typical salt cavern has a height of $300 \mathrm{~m}$ and a diameter of 60-70 m. A number of these salt caverns are in use for natural gas storage and in some other oil, compressed air or other products are stored. Salt caverns can be used to store hydrogen in the same way as they can store natural gas (HyUnder, 2013). In the UK, a salt cavern has been in use for hydrogen storage and in the US, salt caverns have also been used to store hydrogen for many years (see Fig. 7).

In a typical salt cavern, hydrogen can be stored at a pressure of about 200 bar. The storage capacity is about 6,000 ton hydrogen or about $240 \mathrm{GWh}$ (HHV). The total installation costs, including piping, compressors and gas treatment, are about $€ 100$ million (Michalski et al., 2017). For comparison, if this amount of energy would be stored in batteries, with costs of $100 € / \mathrm{kWh}$, the total investment cost would be $€$ 24 billion.

In a recent study by Jülich research center (Caglayan et al., 2020), the potential for hydrogen storage capacity in salt caverns, that are especially leached for hydrogen storage, was investigated (see Fig. 8). There is a huge potential for hydrogen storage in salt caverns all over Europe. Total onshore salt cavern storage capacity is 23,200 TWh of which 7,300 TWh could be developed taking into account a maximum distance 


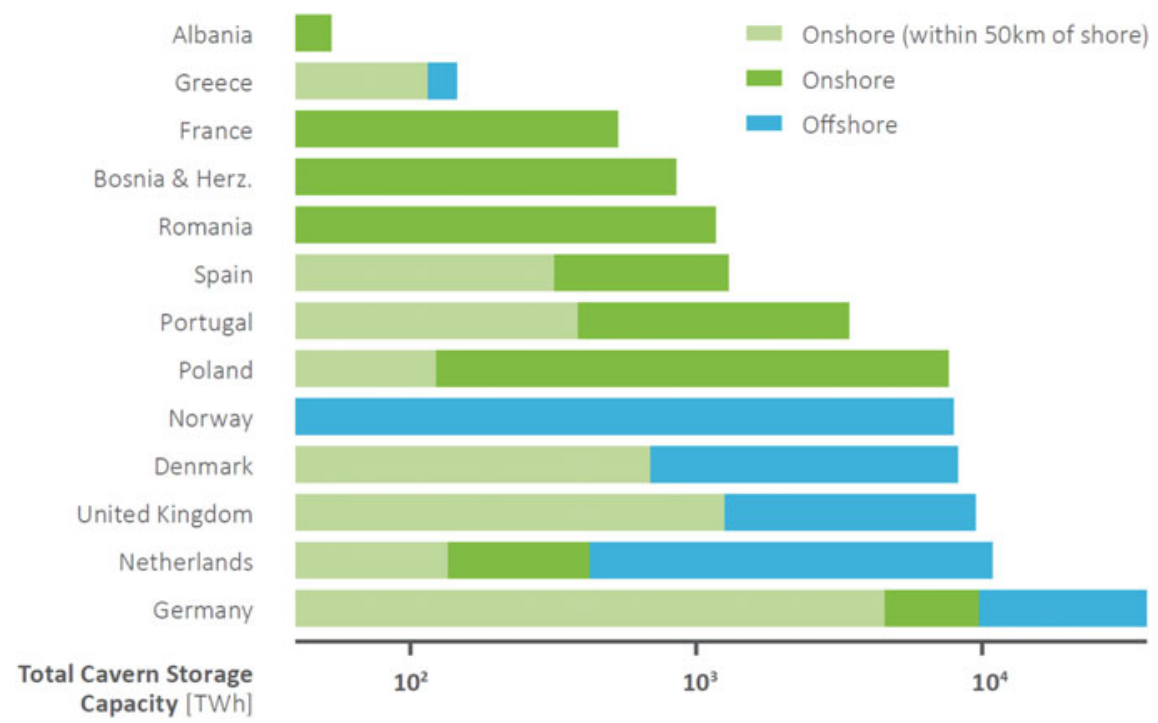

Fig. 8 The potential hydrogen storage capacity in salt caverns in Europe (Caglayan et al., 2020)

to the shore of $50 \mathrm{~km}$, called the constrained storage capacity. This maximum limit is set for the brine disposal. The offshore storage capacity is even larger than the onshore capacity, 61,800 TWh. It should be noted that the salt cavern storage capacity potentials are even larger than total final energy consumption in Europe. Although not studied so far, a substantial potential for hydrogen storage in salt caverns is available in North Africa too.

\section{A Different Approach}

By 2050 when Europe's energy system is largely based on variable renewables, hydrogen is indispensable for transport and storage. Electricity demand will increase up to 2050, but there is a need for green molecules too. And, in an electricity system based on renewable energy resources, the need for hydrogen for storage and providing balancing power is evident.

The shares of hydrogen, presented in recent scenarios are by no means the maximum levels, nor do they represent the optimum. Several scenarios have tried to estimate the increasing demand for green hydrogen in Europe over time, most recently in the Hydrogen Roadmap by the Fuel Cells and Hydrogen Joint Undertaking (FCHJU 2019). This Roadmap estimates that hydrogen could comprise 2,250 TWh or $24 \%$ of Europe's total final energy demand including feedstock in 2050, using a gradual phasing-in approach, see Fig. 9: 


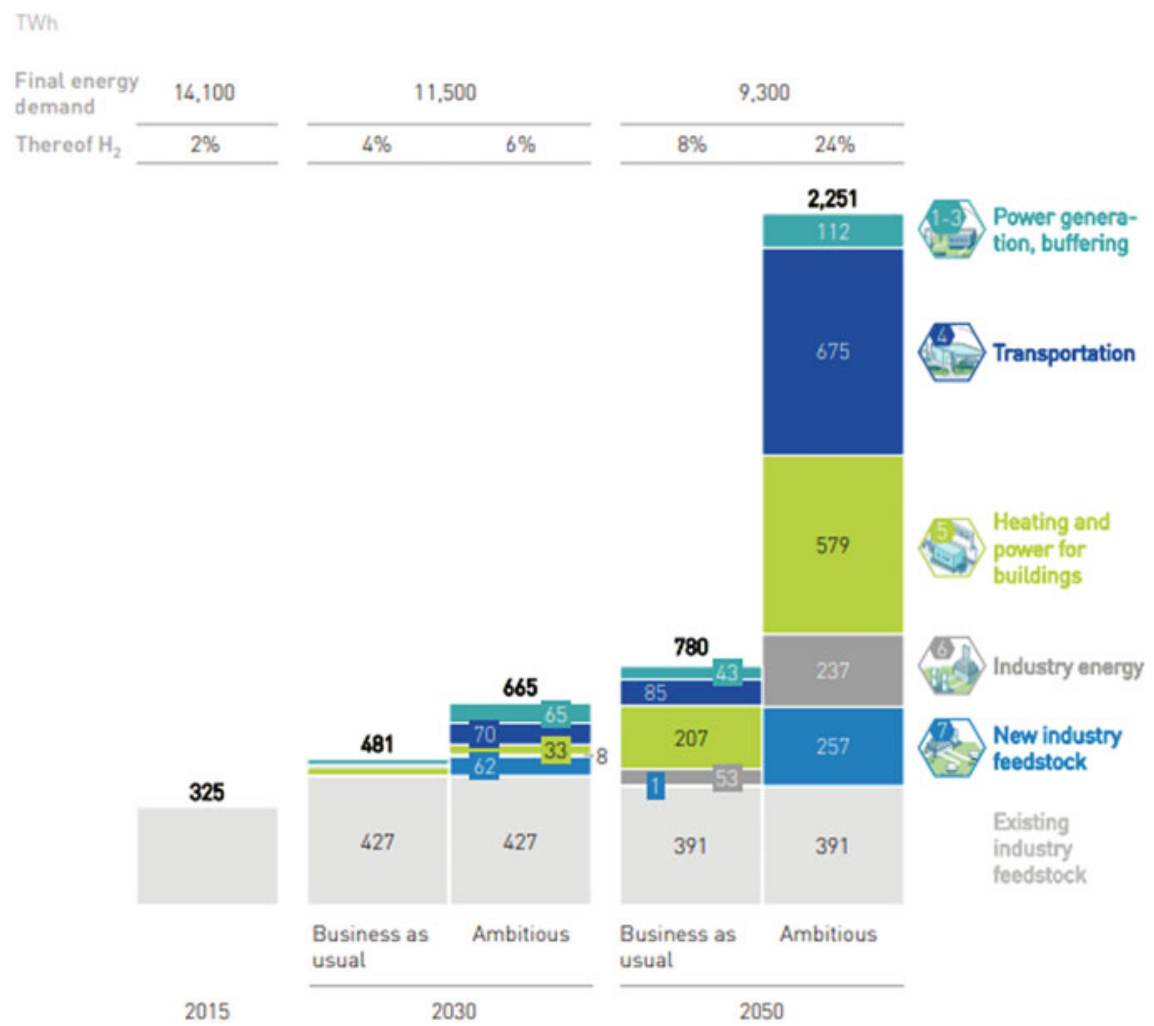

Fig. 9 Final energy demand including feedstock in the EU28 and the share of hydrogen demand for a business as usual and ambitious scenario, from the Hydrogen Roadmap (FCHJU, 2019)

Such scenarios typically use a bottom-up approach in a consultative process, analyzing various end-use sectors such as transport, the built environment, industry and the energy sector. Although there is merit in this approach by applying industry's collective knowledge and a deep-dive in these sectors, the fundamental flaw lies in the fact that at present there is no market for green hydrogen, and it is therefore very difficult to estimate e.g., adoption rates in industry, for fuel cell vehicles or the willingness among consumers to choose between green gas or all-electric solutions for their domestic energy needs.

Therefore, a different approach is proposed to realize a sustainable and inclusive energy system. A sustainable and inclusive energy system that is reliable, secure, affordable, accessible and fair. But above all, could be realized cheaper and faster than presented in recent scenarios by the EU and others. This approach could therefore offer a more realistic pathway for a climate-neutral and fully renewable energy system in the European Union by 2050.

1. Re-use gas infrastructure

2. Develop hydrogen storage 
3. 50-50-50; Final energy demand in $2050,50 \%$ electricity and $50 \%$ hydrogen

4. Europe needs North Africa for green hydrogen.

\section{Re-Use Gas Infrastructure}

Discussing the role of infrastructure in the energy transition, it may be more appropriate and insightful to look back and learn from the introduction of electricity and natural gas 100 and 50 years ago. Electricity and gas grids were built by governments and the service was offered to consumers, who rapidly stopped burning coal and candles in their houses and adopted these new energy sources in their industrial processes.

Following this analogy, instead of a gradual phasing in of green hydrogen, a more ambitious approach based on infrastructure development is therefore proposed. The fundamental philosophy is to make green hydrogen available at scale and costeffectively and replace fossil fuels as quickly as possible by repurposing the current natural gas infrastructure to carry green hydrogen. Since the transmission and distribution infrastructure is already to a large extent available, the focus can be on developing electrolyzer capacity, which is an opportunity for European market leadership. Hydrogen's intrinsic quality as a transport fuel, its ubiquitous characteristics in industrial processes and ability for storage and long-range transport will lead to a rapid market uptake in Europe.

Initially a combination of blue and green hydrogen would be required to produce enough volume to convert a meaningful part of the European gas transport infrastructure. Over time blue hydrogen would be phased out and replaced by green hydrogen. At the latest in 2050 blue hydrogen will be fully phased out.

Of course, the electricity grid needs to be expanded and drastically modernized too, when a $50 \%$ share of electricity in final energy use is foreseen. However, the capacity in the electricity transport grid today is about 10 times less than the capacity in the gas transport grid. Besides, the cost for converting the gas grid to hydrogen will be much less, most probably a factor of 100 less, than building new electricity transmission grid capacity. And the natural gas grid, to a large extent, already exists, facilitating a much faster integration of renewable resources. A smart combination of expanding the electricity grid and at the same time re-using and expanding the gas grid for hydrogen will contribute to a cheaper energy infrastructure, at the same time realizing a renewable energy system faster.

\section{Develop Large Scale Hydrogen Storage}

In a future renewable energy system, largely based on variable renewable energy production and considering large scale fluctuations in daily, weekly and seasonal energy demand, large scale energy storage is needed. Today natural gas storage 
plays that vital role, with gas stored in empty gas fields, porous rock formations and salt caverns. Hydrogen can take over that role, especially by storing hydrogen in salt caverns, both existing and newly excavated. Storage capacity for natural gas comprises $18 \%$ of total gas consumption in the EU. In 2050, when the energy system is based on renewable energy sources, an assumed storage capacity of about 20-30\% of final energy consumption is needed. Salt caverns can provide enough hydrogen storage capacity for this, catering for seasonal storage but also to keep a strategic energy reserve.

Large scale, seasonal and strategic energy storage can be provided by salt caverns relatively cheaply. However, battery storage will provide shorter term storage; hourly and daily storage and frequency control services for the electricity system can be provided by electrochemical batteries. But also, smart grids, demand side management, strengthening interconnections and other balancing instruments will be necessary to operate the electricity system reliably and cost-efficiently.

\section{0-50; 2050 Final Energy Demand Split in 50\% Electricity and 50\% Hydrogen}

Europe's final energy demand including feedstock and energy for international transport (international shipment and air-traffic), is estimated to be 12,000 TWh by 2050 , based on an analysis of above-mentioned scenarios. If a similar division in energy use between the sectors is assumed as in 2017 (Eurostat, 2017), the final energy use per sector for 2050 is as shown in Table 5.

Today, electricity comprises less than $20 \%$ of final energy demand, including feedstock and international transport. About $80 \%$ of final energy demand are molecules, mainly fossil fuels. A small percentage is heat. The share of electricity in final energy demand is expected to grow 2.5 times until 2050, still leaving a large requirement for green molecules across all sectors. There are few alternatives to hydrogen, if any, to fully replace hydrocarbons in a decarbonized energy system, so electricity and hydrogen will both play an important role as energy carriers in the 2050 energy

Table 5 Share of EU final energy use per sector

\begin{tabular}{l|c|c}
\hline Sector & TWh/a (2050) & Share (2017) (\%) \\
\hline Industry energy & 2,500 & 21 \\
\hline Industry feedstock & 1,300 & 11 \\
\hline Transport in EU & 3,100 & 26 \\
\hline Transport international & 700 & 6 \\
\hline Commercial and services & 1,500 & 12 \\
\hline Households & 2,700 & 22 \\
\hline Other & 200 & 2 \\
\hline OVERALL & 12,000 & 100
\end{tabular}


system. Therefore, a 50-50\% share split of green electricity and green hydrogen in Europe's final energy demand is proposed for all sectors: industry, transport, commercial and households.

Of course, this is a rough estimate and will differ per sector and country. But it is doable in the transport sector, achieving a balanced mix of battery electric mobility for shorter distances, combined with fuel cell vehicles for heavy duty, longer ranges and higher convenience. In international transport and industrial feedstock, hydrogen will most probably have a bigger share than $50 \%$. In these two sectors, there will be also a need for carbon $\left(\mathrm{CO}\right.$ or $\left.\mathrm{CO}_{2}\right)$, to produce chemicals and synthetic fuels, which will originate from biomass or by re-circulating the carbon from waste products. Most industrial high heat demand, currently served by natural gas, can be provided by hydrogen, and the household sector will consist of a mix of all-electric wellinsulated new houses, while a large part of the existing building stock can be heated using hydrogen fuel cells and hydrogen gas boilers. Where the resource is available, district heating systems using geothermal or waste heat will play a role. Interesting future solutions also include the combination of heat pumps and hydrogen gas boilers, or hybrid geothermal heat pumps with fuel cells, in which the hydrogen boiler or fuel cell is responsible for the peak demand in the winter season.

\section{Europe Needs North Africa for Green Hydrogen}

Given a final energy demand of 12,000 TWh in 2050 , with a $50-50 \%$ split between electricity and hydrogen, the question is: "How and where can we produce the necessary energy by renewable resources?"

In the scenarios mentioned above, about 2,000 GW solar, $650 \mathrm{GW}$ wind, together with hydropower and other renewable energy resources, could produce 5,000 TWh electricity in 2050 . Green hydrogen needs to be produced by additional green electricity production capacity in Europe over and beyond the 2,000 GW solar and $650 \mathrm{GW}$ wind capacity. Far offshore wind in the North Sea, Baltic Sea, Mediterranean Sea and in the Atlantic Ocean can produce cost-competitive green hydrogen by transporting this hydrogen to the shore by pipeline. Next to this, wind combined with solar on good locations in Southern Europe (Spain, Italy, Portugal and Greece) could produce cost competitive hydrogen too.

However, a substantial part of the necessary hydrogen needs to be imported from neighboring regions. We currently import a substantial part of our energy from Russia, but North Africa, where green hydrogen can be produced even at lower cost than in Europe and transported through cost-effective pipelines, requires due consideration. In North Africa the solar resources are even better than in Southern Europe and several areas have world class wind speeds. Many countries have ample space available to produce green electricity and hydrogen for their own consumption, but certainly also to export to Europe and even beyond.

Green hydrogen can be imported by ship as liquid hydrogen, ammonia $\left(\mathrm{NH}_{3}\right)$ or methylcyclohexane ( $\mathrm{MCH}$, hydrogen bound to toluene), from additional sources 
further away, like LNG nowadays (IEA, 2019). But at distances below 4,000 km, shipping is more expensive than pipeline transportation (Lanphen, 2019). Therefore, we only consider hydrogen pipeline transport between Europe and North-Africa.

Energy supply and demand need to be balanced at all time. The large seasonal fluctuations in energy demand, especially for space heating, and the variability of solar and wind, require large scale storage capacity. We assume that $20 \%$ of the final energy demand, both for electricity and hydrogen, needs to be supplied via hydrogen energy storage. 1200 TWh final electricity demand must therefore be supplied by electricity production from stored hydrogen. This electricity can be produced by fuel cells, placed close to the demand centers. Expensive electricity transport cost will be avoided and the excess heat from these fuel cells could be used for space heating, if feasible.

An Energy Balance can be constructed, considering the necessary storage volumes (3,630 TWh or 92 million ton hydrogen), the conversion losses from electricity to hydrogen $(20 \%)$, hydrogen to electricity $(40 \%)$, the transport losses for electricity $(5 \%)$ and hydrogen $(2 \%)$ and the hydrogen storage losses $(10 \%)$, see Fig. 10. The necessary primary energy (electricity) to deliver 12,000 TWh final energy demand, is $15,710 \mathrm{TWh}$. This yields an overall system efficiency of $76 \%$, a little better than today's $72 \%$. However, in a fully renewable energy system, not based on finite energy sources, this efficiency figure loses relevance. In the future, it is not about system efficiency, but about system cost.

Important to note is that from this $15,710 \mathrm{TWh}$ primary energy production, 8,450 TWh, 54\%, is produced in Europe and 7,260 TWh, or 46\%, is produced in North Africa. It should be noted that this is a marked improvement over our current situation, where Europe imports $55 \%$ of its primary energy demand. Considering the annual hydrogen production, 8,520 TWh in total, more than $2 / 3$ needs to be imported from North Africa, see Table 6. It clearly shows that for a fully renewable energy system in

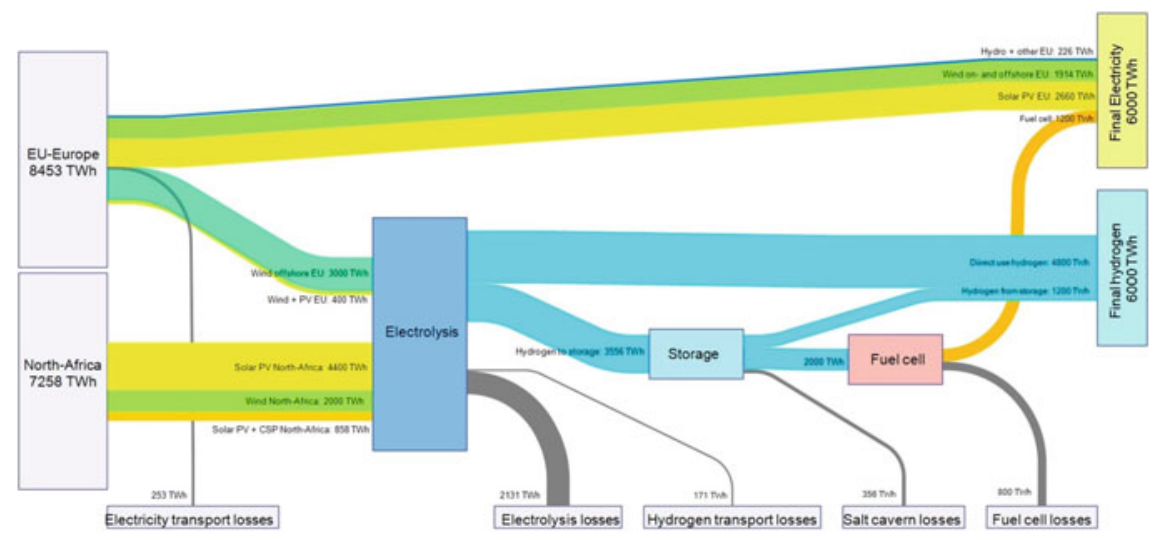

Fig. 10 Energy balance European Union 2050; primary energy production is 15,710 TWh, with final energy consumption amounting to $12,000 \mathrm{TWh}, 50 \%$ electricity and $50 \%$ hydrogen 
Table 6 Primary energy production in Europe and North Africa, for use in the EU in 2050

\begin{tabular}{|c|c|c|c|c|}
\hline $\begin{array}{l}2050 \text { Primary } \\
\text { energy production }\end{array}$ & $\begin{array}{l}\text { Electricity } \\
\text { capacity (GW) }\end{array}$ & $\begin{array}{l}\text { Electricity } \\
\text { production } \\
(\mathrm{TWh})\end{array}$ & $\begin{array}{l}\text { Hydrogen } \\
\text { production } \\
(\mathrm{TWh})\end{array}$ & $\begin{array}{l}\text { Hydrogen } \\
\text { production (Mton } \\
\text { H2) }\end{array}$ \\
\hline \multicolumn{5}{|l|}{ Europe } \\
\hline Solar PV & 2,000 & 2,800 & & \\
\hline $\begin{array}{l}\text { Wind (onshore + } \\
\text { offshore) }\end{array}$ & 650 & 2,010 & & \\
\hline $\begin{array}{l}\text { Hydro + other } \\
\text { renewables }\end{array}$ & & 240 & & \\
\hline $\begin{array}{l}\text { Additional offshore } \\
\text { wind for hydrogen }\end{array}$ & 600 & 3,000 & 2,400 & 61 \\
\hline $\begin{array}{l}\text { Additional Wind }+ \\
\text { Solar PV for } \\
\text { hydrogen }\end{array}$ & 100 & 400 & 320 & 8 \\
\hline Total Europe & & 8,450 & 2,720 & 69 \\
\hline \multicolumn{5}{|l|}{ North Africa } \\
\hline Solar PV & 2,000 & 4,400 & 3,520 & 89 \\
\hline Wind (onshore) & 500 & 2,000 & 1,600 & 41 \\
\hline $\begin{array}{l}\text { Solar PV + CSP } \\
\text { (hybrids) }\end{array}$ & 170 & 860 & 690 & 17 \\
\hline Total North Africa & & 7,260 & 5,810 & 147 \\
\hline Total & & 15,710 & 8,530 & 216 \\
\hline
\end{tabular}

Europe, we need North Africa to produce cost-competitive solar and wind electricity, converted to hydrogen, for export by pipeline to Europe.

\section{What Needs to be Done?}

Such a renewable energy scenario for Europe, implies a massive program to realize renewable energy capacity both in Europe and in North Africa. About 4,200 GW solar capacity and 1,800 wind capacity needs to be realized. To appreciate the enormous investment, the current installed capacity of all coal fired power plants in the world amounts to 2,000 GW. For conversion from electricity to hydrogen, about $3,400 \mathrm{GW}$ of electrolyzer capacity is needed. And for the conversion from hydrogen to electricity, about $500 \mathrm{GW}$ of fuel cell capacity needs to be installed, see Table 7 .

Next to this, the pipeline capacity between North Africa and Europe needs to be expanded to about $1,000 \mathrm{GW}$, which is about 30 pipelines with a capacity of $33 \mathrm{GW}$ each. In Europe the gas pipeline infrastructure is partly available. However, the production flows of hydrogen are, to a large extent, from the south to the north. This means that, especially from the south of Europe to the north of Europe, the 
Table 7 Capacities in production, conversion, infrastructure and storage that needs to be realized in 2050

\begin{tabular}{|c|c|}
\hline 2050 & To be realized in 2050 (to cater for Europe's energy demand) \\
\hline \multicolumn{2}{|l|}{ Production } \\
\hline Solar capacity & 4,200 GW; 2,000 GW Europe and 2,200 GW North Africa \\
\hline Wind capacity & 1,800 GW; $1,300 \mathrm{GW}$ Europe and $500 \mathrm{GW}$ North Africa \\
\hline \multicolumn{2}{|l|}{ Conversion } \\
\hline Electrolyzer capacity & 3,400 GW; $700 \mathrm{GW}$ Europe and 2,700 GW North Africa \\
\hline Fuel cell capacity & $500 \mathrm{GW}$; in Europe \\
\hline \multicolumn{2}{|l|}{ Infrastructure } \\
\hline Hydrogen pipelines & $\begin{array}{l}1,000 \mathrm{GW} \text { pipeline connection between Europe and North Africa } \\
\text { Re-use existing gas pipeline infrastructure in Europe and North Africa, } \\
\text { conversion from natural gas to hydrogen } \\
\text { Expand pipeline capacity, especially from south to north of Europe } \\
\text { Realize pipeline connections between North African countries from east } \\
\text { to west }\end{array}$ \\
\hline Electricity grid & $\begin{array}{l}\text { Massive capacity expansion of the electricity grid, at least with a factor } 2 \\
\text { on a volume base } \\
\text { Grid re-enforcement and new grids are required between the renewable } \\
\text { electricity production in Northern and Southern Europe and the load } \\
\text { centers } \\
\text { Capacity expansion of interconnections between countries } \\
\text { Realize an electricity grid in and between North African countries }\end{array}$ \\
\hline \multicolumn{2}{|l|}{ Storage } \\
\hline Salt caverns & $\begin{array}{l}15,000 \text { Salt caverns; } 10,000 \text { in Europe, } 5,000 \text { in North Africa } \\
\text { Hydrogen storage in empty gas fields if possible }\end{array}$ \\
\hline Batteries & $\begin{array}{l}\text { Batteries are required, especially for day-night storage; North Africa } \\
\text { could rely much more on battery storage than on hydrogen storage, due } \\
\text { to its climatological conditions }\end{array}$ \\
\hline Heat storage & $\begin{array}{l}\text { Seasonal heat and cold storage for space heating, especially in aquifers } \\
\text { and rock formations. This is important for North-Europe }\end{array}$ \\
\hline
\end{tabular}

hydrogen gas grid needs to be expanded. In Europe also the electricity transport infrastructure needs to be considerably expanded. Final electricity consumption in 2017 was about 3,000 TWh and will be doubled in 2050. On a volume basis, the capacity therefore needs to be expanded with at least a factor of 2 . However, especially the grid capacity from the north and south of Europe to the load centers and the interconnections between the European countries need be expanded much more than a factor of 2 , see Table 7 .

The estimated large-scale storage volume in this scenario is 3,630 TWh or 92 million ton hydrogen. One salt cavern can store about 6,000 ton of hydrogen. So, there is a need for 15,000 salt caverns for hydrogen storage. Although these salt caverns can be realized in Europe, also in North Africa salt cavern storage capacity needs to be realized. $1 / 3$ of the salt cavern capacity needs to be realized in North 
Africa. Next to this there is a need for battery storage, especially for day-night storage and heat and cold storage, especially seasonal storage in aquifers, see Table 7.

An important aspect of this transition is that the end-use conversion technologies need to be replaced. It means e.g., the replacement of all present internal combustion engine vehicles by electric vehicles, both battery and fuel cell hydrogen electric vehicles. But also replacing existing heating equipment in houses, with heat pumps, hydrogen boilers or fuel cells. However, this equipment is replaced every 10-15 years anyhow. Therefore in 30 years' time the replacement of this equipment is manageable.

\section{Towards a Sustainable and Inclusive Energy System}

An inclusive energy transition is about an energy system that is affordable, accessible, secure, reliable and fair (distribution of benefits and burdens) for everyone. A 50\% renewable electricity and $50 \%$ renewable hydrogen system developed in mutual cooperation with North Africa for the benefit of both, whereby everyone is connected to an energy infrastructure including energy storage facilities (electricity, hydrogen), is a good prerequisite for an inclusive energy system.

\section{Affordable}

Renewable electricity is rapidly becoming cheaper than conventional electricity made in nuclear, gas- or coal-fired power plants. Already to date, solar power in Southern Europe and offshore wind in the North Sea does not require subsidy but can be produced and sold at market prices. If a green hydrogen market would develop along the lines sketched here, hydrogen can be produced at $€ 1$ per kg, which is compatible with natural gas prices of $€ 9 / \mathrm{mmbtu}$ or $€ 0.25 / \mathrm{m}^{3}$. Since the energy content of $1 \mathrm{~kg}$ of hydrogen is equivalent to $3.8 \mathrm{~L}$ of gasoline, it is also cheaper than gasoline or diesel at that price point, even discounting the tax on transport fuels.

The advantage of a mutual co-operation with North Africa are two-fold: the economic opportunity for North African economies, and the lower production cost for hydrogen from solar and wind electricity. The resources are better, investment costs lower and space is abundantly available. Hydrogen could be produced for less than $€ 1$ per kg and be competitive with hydrogen produced in Europe, even including pipeline transportation cost.

But the main advantage lies in the infrastructure and storage. The proposed transition would, to a large extent, use the existing natural gas grid and would avoid an expensive and troublesome complete overhaul and large capacity expansion of the electricity grid. Also, storage, especially large-scale seasonal storage for hydrogen can be realized similar to natural gas, in existing and newly realized salt caverns. Hydrogen storage in salt caverns can not only be realized much cheaper, it can be realized faster too. 
An affordable energy system for everyone is not necessarily a system where energy is produced, stored and consumed locally. Especially renewable energy resources show a great variation in production cost around the world. At places with good solar irradiation or wind speeds and cheap land and competitive labour cost, the production cost could be a factor 5-10 lower than at places with moderate solar irradiation or wind speeds, and high land and labour costs. Also, large scale energy storage costs (hydrogen in salt caverns or ammonia in large tanks) are easily a factor of 100 cheaper than small scale storage costs (compressed hydrogen in bottles or electricity in batteries). Therefore, an affordable energy system for everyone will be a smart combination of a large scale and local energy system.

\section{Accessible}

An accessible energy system for everyone is a system whereby everyone has access to clean energy. An important pre-requisite for access to clean energy is a connection to a well-organized energy infrastructure. This could be an electricity, gas or heat grid or a fuelling infrastructure, whereby an electricity grid connection is the most essential one. A combination with a gas infrastructure (hydrogen), especially in Europe, is in many cases useful to deliver the necessary energy for heating at moments of high demand.

The connection to an energy infrastructure needs to be guaranteed. This could be organized by obliging energy transport and distribution companies to connect every consumer and every producer. The question is whether the cost for such a connection needs to be socialized. This seems to be a fair principle, making it possible that all consumers are not only connected to an energy infrastructure, but also could afford to pay for it.

The obligation to connect and socializing energy infrastructure cost seems a good principle, but how to implement these principles in a fully renewable energy system, with electricity and hydrogen as the main energy carriers? Two types of questions arise: connecting to which infrastructure and socializing over what energy? We illustrate these questions with two examples, informing the debate for policy makers.

- If a far offshore wind farm is realized, is there an obligation to connect to an electricity grid or can the wind farm owner choose to connect to either the electricity or the hydrogen grid? Or can the energy transport companies (TSO's) together decide to connect to a hydrogen grid and/or an electricity grid?

- If the natural gas infrastructure is converted to a hydrogen infrastructure, do we socialize the cost over the hydrogen consumption only, or do we socialize these costs in a transition period over the total gas (natural gas and hydrogen) consumption? Or should we socialize the cost for all infrastructure (electricity, natural gas, hydrogen) over all energy consumption? 


\section{Secure}

Security of supply is always an important consideration for Europe, especially because energy is a vital part of the economy. Europe is currently a net energy importer and will likely continue relying on imported energy for a share of its demand, also in a future renewable energy system. However, a system as described here substantially reduces the import share of currently $55 \%$ to $46 \%$, with a more diverse set of countries supplying Europe.

The infrastructure proposed also carries important benefits for North African nations, enabling them to secure their own energy supply and trade hydrogen and electricity among each other and exporting to Europe and other parts of the world, earning foreign exchange and boosting their economies.

\section{Reliable}

To deliver energy at the right time and place, an energy infrastructure with enough transport and distribution capacity is necessary together with enough storage capacity at different time scales (seasonal, weekly, daily, hourly, minutes and seconds). An allelectric system, whereby only electricity is transported, stored and distributed, needs a gigantic and very expensive expansion of the electricity grid and battery storage capacity. In Europe especially, with seasonal storage needs due to space heating, such an all-electric system seems prohibitively expensive and almost impossible to realize. In North-Africa, however, with less seasonal variation and where solar production matches cooling demand, an all-electric solution with battery storage to cater for the evening peak, seems a good and cost-effective solution. At the same time, demand for hydrogen for mobility and industry will also develop in North Africa.

In Europe, due to its existing natural gas infrastructure, a smart combination of a green electricity and hydrogen energy system could offer a reliable and costeffective solution. Of course, there is a need to modernize and increase the capacity in the electricity grid, together with installing battery and capacitor capacity for frequency response and short-term storage. But especially for weekly and seasonal storage, hydrogen offers a much cheaper solution, especially by storing hydrogen in salt caverns.

\section{Fair}

The development of a clean energy system for both Europe and North Africa in mutual co-operation is beneficial for both. Europe cannot produce the renewable energy it needs in Europe alone, as it simply does not have enough solar and wind resources, nor available and affordable land. North Africa on the other hand, has 
these resources abundantly available and can produce enough clean energy for its own demand, as well as for export to Europe and other parts of the world. North Africa, however, lacks the technology, capital and a well-educated labour force to develop a clean energy system on its own.

Therefore, cooperation on the development of a renewable, fully decarbonized energy system is for the benefit of both. It creates future-oriented economic development, jobs and welfare in North Africa by developing a clean energy system for their own use and export. In Europe, a clean, reliable and affordable energy system can be realized by re-using part of the existing assets and infrastructure, in combination with renewable energy production in Europe and import from North Africa. Europe can build a sustainable, circular and cost-competitive industry, based on green electricity and green hydrogen supply at competitive cost. And Europe and North Africa together could be world market leaders in renewable energy system technology and system production and realization, especially in electrolyzer, gasification and fuel cell technologies, hydrogen, electricity and heat storage technologies, energy infrastructure and conversion technologies, green chemistry and synthetic fuels.

Improving livelihoods in Africa will reduce the migration of people from Africa, seeking economic opportunities in Europe. The joint development of a clean energy system could provide a perspective for a better life and future in these North African countries. Such a development is fair from both the European and North African perspective.

\section{Conclusions and Required Political Agenda}

A European energy system based on 50\% green electricity and 50\% green hydrogen, developed in mutual co-operation with North Africa for the benefit of both, would have many advantages:

- The energy system would be entirely clean, with no $\mathrm{CO}_{2}$ emissions, which meets the Paris Agreement but would also have tremendous health benefits due to reduced local emissions in European and African cities.

- The system would be a shift away from a system based on finite resources, which invariably leads to scarcity and higher cost towards the end, to a system entirely based on renewable energy resources with technologies becoming cheaper over time.

- A European ambition level based on proven but largely undeveloped technologies (electrolyzers, gasifiers, fuel cells, hydrogen storage technologies, new domestic appliances, hydrogen-electric mobility, synthetic green chemicals and fuels) provides a tremendous opportunity for global technology leadership, with associated economic momentum and job creation.

- The infrastructure required for the new system will be largely based on the already existing natural gas grid and avoids an expensive overhaul and massive capacity expansion of the electricity grid. 
- The energy system would be reliable, with balanced supply and demand at all times and every place, due to large-scale, cheap hydrogen storage, especially in salt caverns, together with a public hybrid electricity-hydrogen infrastructure.

- Developing a clean energy system in cooperation between Europe and North Africa unlocks access to vast and cheap renewable energy resources for Europe and North Africa, whilst supporting the development of affordable, reliable and clean energy for North Africa itself.

- Europe and North Africa can both profit from this cooperation, it creates economic development, new business, new export, jobs and welfare in North Africa as well as in Europe

- Developing a clean energy system in North Africa, for own use and export, creates jobs, welfare and better living conditions reducing the necessity for people to migrate to Europe.

However, such a "moonshot" program requires tremendous political and societal will on a level rarely seen, not only within Europe but also between Europe and North Africa. To enable the transition and avoid the exclusion of large parts of the current energy industry, careful thought must be given to minimize stranded assets and include as many players as possible. An environment for investments in Europe and North Africa needs to be designed, in mutual co-operation, for the benefit of both.

The following are necessary considerations for an action agenda:

- A strong, clear and lasting political commitment is necessary, embedded in a binding European strategy with clear goals stretching over several decades.

- A new type of public private partnership on a pan-European level must be crafted, with the aim to create an ecosystem to nurture a European clean energy industry that has the potential to be world leading in the field. This partnership should include existing energy industry as well as innovative newcomers.

- A novel enabling regulatory environment and associated market design is required for the necessary investments, whilst keeping the system costs affordable.

- An integrated electricity-hydrogen infrastructure and storage system policy framework needs to be designed, with fair and reliable access to energy for everyone.

- Finally, above all, a new, unique and long-lasting mutual cooperation on the political, social and economic level between the EU and North Africa needs to be designed and realized. This cooperation needs to be based on mutual respect and trust, considering each other's cultural, social and economic backgrounds.

\section{References}

BP. (2019). "BP energy outlook, 2019 edition."

Bundesnetzagentur. (2019). "Quartalsbericht zu Netz-und systemsicherheitsmaßnahmen; Gesamtjahr und viertes quartal 2018.” May. https://www.bundesnetzagentur.de/SharedDocs/Downloads/ DE/Allgemeines/Bundesnetzagentur/Publikationen/Berichte/2019/Quartalsbericht_Q4_2018. pdf?_blob=publicationFile $\& \mathrm{v}=4$ 
Bünger, U., Michalski, J., Crotogino, F., \& Kruck, O. (2016). Compendium of hydrogen energy. In Large scale underground storage of hydrogen for the grid integration of renewable energy and other applications, (pp. 133-163). Woodhead Publishing.

Caglayan, D., Weber, N., Heinrichs, H. U., Linßen, J., Robinius, M., Kukla, P. A., \& Stolten, D. (2020). Technical potential of salt caverns for hydrogen storage in Europe. International Journal of Hydrogen Energy, 45(11), 6793-6805. https://doi.org/10.1016/j.ijhydene.2019.12.161

Carbon Capture and Storage, Association. (2019). https://www.ccsassociation.org/faqs/ccs-glo bally/

Dii, \& FraunhoferISI. (2012). "Desert power 2050 perspectives on a sustainable power system for EUMENA." Presented at SWP Berlin, 22 May.

DNVGL. (2017). "Verkenning waterstofinfrastructuur (in Dutch)." Rapport for Ministery of Economic Affairs.

DNV-GL. (2018). "Energy transition outlook 2018, a global and regional forecast of the energy transition to 2050." https://eto.dnvgl.com

European Commission. (2018). "A clean planet for all; A European strategic long-term vision for a prosperous, modern, competitive and climate neutral economy." Brussels.

Eurostat. (2019). 7 February. https://ec.europa.eu/eurostat/documents/2995521/9549144/8-070 22019-AP-EN.pdf/4a5fe0b1-c20f-46f0-8184-e82b694ad492

EurostatEnergy. (2019). "EU28 energy balances february 2019 edition." https://ec.europa.eu/eur ostat

Eurostatgas. (2019). "Natural gas supply statistics; Consumption trends." https://ec.europa.eu/eur ostat/statistics-explained/index.php?title=Natural_gas_supply_statistics\#Consumption_trends

EurostatGuide. (2019). "Energy balance guide draft." 31 Januari. https://ec.europa.eu/eurostat/ documents/38154/4956218/ENERGY-BALANCE-GUIDE-DRAFT-31JANUARY2019.pdf/cf1 21393-919f-4b84-9059-cdf0f69ec045

Eurostatimports. (2019). "EU import of energy products—recent developments." May. https://ec. europa.eu/eurostat/statistics-explained/index.php?title=EU_imports_of_energy_products_-_rec ent_developments

EWEA. (2017). “2050: Facilitating 50\% wind energy.” https://www.ewea.org/fileadmin/files/lib rary/publications/position-papers/EWEA_2050_50_wind_energy.pdf

FCHJU. (2019). "Hydrogen roadmap Europe, a sustainable pathway for the European energy transition." https://fch.europa.eu

Hydrogen Council. (2017). "Hydrogen scaling up; a sustainable pathway to the global energy transition." November. https://hydrogencouncil.com/study-hydrogen-scaling-up/

HyUnder. (2013). "Assessment of the potential, the actors and relevant business cases for large scale and seasonal storage of renewable electricity by hydrogen underground storage in Europe." EU report 14 August 2013 www.fch.europa.eu

IEA. (2019). "The future of hydrogen, seizing today's opportunities." Report prepared by the IEA for the G20 Japan.

IRENA. (2015). "Africa 2030; roadmap for a renewable energy future." https://www.irena.org/pub lications/2015/Oct/Africa-2030-Roadmap-for-a-Renewable-Energy-Future

James, B., DeSantis, D., Huya-Kouadio, J., Houchins, C., \& Saur, G. (2018). "Analysis of advanced H2 production \& delivery Pathways." June. https://www.hydrogen.energy.gov/pdfs/review18/ pd102_james_2018_p.pdf

Kiwa. (2018). "Toekomstbestendige gasdistributienetten (in Dutch)." Rapport for netbeheer Nederland.

Lanphen, S. (2019). "Hydrogen import terminal; providing insights in the cost of supply chain of various hydrogen carriers for the import of hydrogen." MsC thesis, TU Delft, Delft.

Michalski, J., Büngerz, U., Crotogino, F., Donadei, S., Schneider, G. S., Pregger, T., Cao, K. K., \& Heide, D. (2017). "Hydrogen generation by electrolysis and storage in salt caverns: Potentials, economics and systems aspects with regard to the German energy transition." International Journal of Hydrogen. 
Morgan, S. (2019). "Five EU countries call for $100 \%$ renewable energy by 2050." 5 March. https://www.euractiv.com/section/climate-strategy-2050/news/five-eu-countries-callfor-100-renewable-energy-by-2050/

Nordstream. (2014). "Secure-energy-for-europe-full-version." https://www.nord-stream.com/ media/documents/pdf/en/2014/04/secure-energy-for-europe-full-version.pdf

Nordstream. (2017). Factsheet the nordstream pipeline project. https://www.nord-stream.com/

Ram, M., Bogdanov, D., Aghahosseini, A., Gulagi, A. S., Oyewo, A., Child, M., Fell, H.-J., \& Breyer, C. (2017). Global energy system based on $100 \%$ renewable energy—Power sector. Study by Lappeenranta University of Technology and Energy Watch Group.

Shell. (2018). "Shell scenario SKY, meeting the goals of the Paris agreement." https://www.shell. com/skyscenario

Timmerberg, S., \& Kaltschmitt, M. (2019). Hydrogen from renewables: Supply from North Africa to central Europe as blend in existing pipelines-Potentials and costs. Applied Energy, 237, 795-809

van Wijk, Ad., \& Chatzimarkakis, J. (2020). Green hydrogen for a European green deal, a 2x40 GW initiative. Hydrogen Europe. ISBN 978-90-827637-1-3

van Wijk, A., van der Roest, E., \& Boere, J. (2017). Solar power to the people. Allied Waters. ISBN 978-1-61499-832-7 [online]. https://doi.org/10.3233/978-1-61499-832-7-i

Varadi, P. F., Wouters, F., \& Hoffmann, A. R. (2018). The sun is rising in africa and the middle east-On the road to a solar energy future. Pan Stanford Publishing Co ISBN-10-9814774898.

Open Access This chapter is licensed under the terms of the Creative Commons Attribution 4.0 International License (http://creativecommons.org/licenses/by/4.0/), which permits use, sharing, adaptation, distribution and reproduction in any medium or format, as long as you give appropriate credit to the original author(s) and the source, provide a link to the Creative Commons license and indicate if changes were made.

The images or other third party material in this chapter are included in the chapter's Creative Commons license, unless indicated otherwise in a credit line to the material. If material is not included in the chapter's Creative Commons license and your intended use is not permitted by statutory regulation or exceeds the permitted use, you will need to obtain permission directly from the copyright holder.

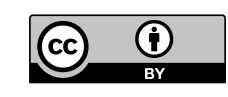

